\title{
NEOLITHIC ARTEFACTS, SIGNS AND SCENES FROM SOUTHERN ROMANIA
}

RADIAN-ROMUS ANDREESCU

\section{REZUMAT:}

Printre descoperirile din epoca neolitică se află multe artefacte care sunt decorate cu diverse elemente, de obicei geometrice, majoritatea incizate. Artefactele sunt variate, multe figurine, vase, mai rar obiecte din lut de tipul tăblițelor de la Tărtăria. Articolul de față a adunat câteva piese, unele descoperite în ultimii ani, decorate prin incizare.

O primă categorie este formată din mici obiecte din lut care au pe suprafaţa lor lini incizate dispuse în diverse combinații. A doua categorie este formată din doua piese din lut care sunt decorate cu scene formate din personaje schematic redate combinate cu alte elemente. Descoperirile au fost făcute în zona de centru sud a României, în așezările neolitice de la Vădastra, Măgura-Buduiasca și Hotărani şi aparţin culturilor Starčevo-Criș, Dudești și Vădastra, mil. VI BC.

Semnificația acestor artefacte, mai precis a semnelor de pe ele, este o temă intens dezbătură de câteva decenii, unii cercetători identificând în acestea elementele unei scrieri neolitice.

\section{ABSTRACT:}

There are many artefacts among the discoveries of the Neolithic period decorated with various elements, usually geometrically shaped, and mostly incised. The artefacts are diverse, there are many figurines, vessels, and seldom clay objects such as the tablets from Tărtăria. This article has gathered several artefacts, some of them discovered in recent years, decorated by incision.

A first category consists of small clay artefacts that have on their surface incised lines arranged in various combinations. The second category consists of two pieces of clay that are decorated with scenes portraying schematic characters combined with other elements. The discoveries were made in south-central Romania, in the Neolithic settlements of Vădastra, Măgura-Buduiasca and Hotărani and belong to the Starčevo-Criş, Dudești and Vădastra cultures, $6^{\text {th }}$ millennium BC.

The meaning of these artefacts, or more precisely the meaning of the signs on them, has been an intensely debated topic for several decades, some researchers identifying in them elements of a Neolithic writing.

CUVINTE CHEIE: Neolitic, semne, scriere, scene, mesaj vizual.

KEYWORDS: Neolithic, signs, writing, scenes, visual message.

What we call the Neolithic or Neo-Eneolithic age is a complex period, a turning point in human history, unfortunately little understood and explained. One of the most sensitive issues of this period is the existence of a Neolithic writing. The subject aroused interest due to the fact that some Neolithic artefacts bear various signs, the most famous being the tablets from Tărtăria ${ }^{1}$. In addition, many anthropomorphic figurines that are decorated with a series of signs, usually incised, were discovered.

The discovery of a clay tablet with an incised decoration among the materials from older excavations at the Vădastra ${ }^{2}$ site made us reevaluate some interesting discoveries made in south-central Romania, with the Olt River

\footnotetext{
For the tablets from Tărtăria see Vlassa 1963, 485-494 and Lazarovici, Lazarovici and Merlini 2011.

2 Mateescu, 1971, 643-650 with bibliography; for a synthesis of research from Vădastra see Dragoman 2013.
} 
as main axis. The discoveries were made in Măgura-Buduiasca ${ }^{3}$ sites on the Teleorman Valley ${ }^{4}$ and Hotărani ${ }^{5}$, Olt County, and belong to the Starčevo-Cris, Dudești and Vădastra cultures that evolved in this area in the 6th millennium BC (P1. I/1).

Chronologically, the oldest artefact was discovered at Măgura-Buduiasca (Pl. I/2), in a Starčevo Cris III context dated to the first part of the 6th millennium $\mathrm{BC}^{6}$. The small piece is made of a compact clay paste, gray-yellow in color (P1. II/1). It has a relatively trapezoidal shape with rounded corners. The lower part and the upper right part are missing. The piece is decorated with wide incisions, quite carelessly drawn. The decoration is on the front of the piece, certain elements extending on the sides, barely visible. There are also several incisions at the top of the piece. A horizontal line divides the decor into two registers. It consists of seemingly irregularly arranged lines, in various positions, vertical, oblique, angled and even in the approximate shape of a rhombus. The incised lines appear to have been encrusted with red paste. The piece is perforated laterally at the top, probably to be hung ${ }^{7}$.

The second artefact, also discovered at Măgura-Buduiasca, this time in a context dated to the middle of the 6th millennium BC, the Dudești culture, represents a small object made of gray-yellow clay paste, with a rectangular parallelepiped shape, slightly thicker at one end (Pl. III/2a, 2b). The piece is covered on all sides with incised lines. The incisions are arranged quite irregularly, some forming bands of oblique lines, others combined in angular shapes. Some appear to form some kind of rhombus with few lines on the inside, surrounded by other incisions. At the ends there is a quadrilateral, quite roughly drawn, with lines inside ${ }^{8}$.

The clay tablet discovered at Vădastra (Pl. II/2a, 2b) belongs to the same category of engraved pieces with various signs. The piece of gray-brown clay, slightly damaged, has a rectangular shape with rounded corners. The decoration, rather carelessly incised, covers almost the entire piece. On one side it has angled lines, framed at the top and bottom by two horizontal lines. On the other side it has two spirals and other irregular lines, next to a small rhombus. On the sides there is a vertical incision. The piece belongs to the Vădastra culture (last quarter of the 6th millennium $\mathrm{BC}$ ).

Unlike these three pieces, two other artefacts have a decor that seems to suggest a scene, a picture, through schematic human characters, combined with other elements, all incised.

The first one, discovered at Măgura-Buduiasca, belongs to the Vădastra culture (Pl. III/1). The piece, of about 5 $\mathrm{cm}$ in length, has a cylindrical shape, slightly elongated at one end. It was made of gray-yellow clay with pebbles in the composition and it has signs of secondary burning. The whole body was covered with incised marks. The reconstruction of the circular decor revealed an interesting image, a scene with two excessively schematic characters. A silhouette with an elongated head is outlined on the right side of the scene. Two incised lines appear to represent the arms, one at the back and one at the front. In front of the arm and above it there are other incised lines. Several lines at the bottom of the picture would suggest that the character is either sitting or standing on some kind of podium. On the left is another silhouette that seems to have a bent leg, the head and torso bent slightly forward, above the head there can be seen the arm of the other character. ${ }^{9}$ Thus the unfolding decor suggests an image, a scene in which there are two schematically portrayed characters ${ }^{10}$.

The second artefact was also discovered in a settlement belonging to the Vădastra culture in Hotărani ${ }^{11}$, near the Olt River and represents a special discovery in the context of this culture (Pl. IV). The piece, small in size (D. base $=5 \mathrm{~cm}, \mathrm{H}=3.5 \mathrm{~cm}$ ), made of gray paste, has a conical shape with a convex base on the inside. At the top it has a strange element, partially missing, which seems to be some kind of handle, or, less likely, the schematic representation of a small house. The piece was interpreted as representing a small lid with a handle ${ }^{12}$. The body is covered with an incised decoration, rather awkwardly executed. The unfolding decor reveals the existence of a scene, this time more complex, with two schematic characters along with other elements more difficult to decipher.

\footnotetext{
3 Andreescu, 2007, 53-65.

4 The research has been carried out within the Southern Romania Archaeological Project, in which have participated the National History Museum of Romanian, the Cardiff University and the Teleorman County Museum (see Andreescu 2007 with bibliography).

5 Nica 1971, 5-33.

6 Initially, the piece was attributed to the Dudești culture (Andreescu 2009). The re-evaluation of the archaeological context places it in Starčevo-Cris III culture.

7 Andreescu 2009, 78, P1. 6/4.

8 Andreescu 2009, 78, P1. 6/3.

9 Andreescu 2007, 57, P1. 5/1.

10 Similar artefacts, with various incised signs, have been discovered at the south of the Danube, in the Karanovo IV culture (Nikolov 2006, p. 59), but they do not seem to represent a scene with characters like the one from Măgura-Buduiasca.

11 Nica 1971, 5-33.

12 Popovici 2010, 65-70.
} 
On the left side of the image there are two rectangles with lines inside. Further there is a set of zigzagging, winding and short lines. Next to them is a human figure represented by several incisions. The head is relatively trapezoidal, one arm is bent from the elbows down, the other is oriented towards the head. The body is represented by a vertical incision and the legs are apart. Further there is a series of interconnected zigzagging and winding lines, along with curved and angled lines, some connected together as well. The set of zigzagging and winding lines seems to be a repetition of the set described above, but much more carelessly executed. Another human figure with a rectangular head, an arm bent at the elbows and the body represented by a vertical line is portrayed in an equally awkward manner. The lower part ends with a kind of rather carelessly drawn triangle. The scene ends with a set of winding, curving and angled lines in various combinations drawn quite randomly. Thus, a scene is outlined with two characters surrounded by combinations of lines, more or less skillfully executed, next to which are the two rectangles.

This batch of only five artefacts is evidence of a complex situation regarding what we would call the visual symbolism of the Neolithic civilization.

The archaeological contexts in which they were discovered are nothing special. The ones from Măgura-Buduiasca and Hotărani were discovered in pits or in the archeological level, together with other archeological materials, such as ceramic fragments, osteological materials, artefacts, without any other element to indicate a special significance of that certain complex. For the piece from Vădastra the archaeological context is unknown.

The artefacts are divided into two categories, the first contains three clay objects that have various signs incised on them, mainly oblique and angled lines, but also spirals or rhombuses; the other category includes two objects that have scenes incised on them with excessively schematic characters.

What are these artefacts? What are the signs on some of them? What are the characters from the scenes on the two artefacts trying to tell us?

We can only construct various hypotheses, but these hypotheses are impregnated with subjectivism due to our historical background. For example, a plausible hypothesis about the trapezoidal artefact is that it could be a pendant given the perforation at the top (Pl. II/1). What are the signs on it? One explanation I find in my historical background would be that these signs give this artefact a special functional feature, namely that of protecting the bearer against evil spirits. But is that so?

The second parallelepiped-shaped artefact is covered on all sides with incised marks arranged in angles, in rows of oblique dashes, triangles and something resembling a rhombus (Pl. III/2a, 2b). About this small object I could speculate that it could have been part of a kit of divination, of predicting the future, an explanation also found in my historical background.

The last artefact is a small clay tablet that has spirals on one side and short angled lines on the other side ${ }^{13}$ (Pl. $\mathrm{II} / 2 \mathrm{a}, 2 \mathrm{~b})$. I find it hard to speculate about this piece; other pieces somewhat similar, with various signs have been discovered in other cultures also, such as Vinča or Cucuteni, some of them being interpreted as representing breads ${ }^{14}$.

The existence on the three artefacts of relatively similar signs, short, oblique, angled lines, or geometric elements similar to triangles or rhombuses is interesting.

The other two artefacts are different from these and their significance seems to be closely related to the scenes they represent.

The small clay cylinder belonging to the Vădastra culture reminds of the well-known Mesopotamian seals, stone cylinders with various scenes, more or less realistic, engraved on them. The latter had various uses, administrative tools - seals, jewelry, amulets. However, the pieces are from much later (they appear around the middle of the 4th millennium BC) than the Măgura-Buduiasca cylinder dated to the last quarter of the 6th millennium BC. Looking at the unfolding of the play, my impression is that we have a character in a dominant position who seems to be sitting on a chair (throne) or a podium. In front of him, another character seems to be kneeling, with his head bowed. The arm of the first character is above the head of this character and seems to hold an indefinite object marked by several incisions (Pl. III/1). My historical background suggests that we have a representation of a scene of obedience, worship or perhaps blessing, such scenes being documented in various spaces and times.

The second artefact, the one resembling a lid, has an incised scene with clearer characters, even if they are also very schematic. The first character is better made and is presented in a certain posture, with the right arm bent

13 Somewhat similar tablets were discovered in southwestern Romania, in the Danube valley, at Rast, a settlement belonging to Vinča culture. The incised decoration is special and resembles the decoration on the vessels (Dumitrescu 1980, 53-54, Pl. LIII/1-3; Pl. LVI/1).

14 Lazarovici 2013, 560-573. 
from the elbow down, the left one seems to support the head, the legs apart. The attitude of this character reminds of the statuettes modeled in the so-called "thinker" position, the most famous being the Cernavodă Thinker, from the Hamangia ${ }^{15}$ culture (late 6th - first half of the 5th millennium BC). We find the same position in many of the anthropomorphic figurines of the Gumelnița ${ }^{16}$ culture (5th millennium BC). The second character, more awkwardly incised, has a triangle at the base, which could indicate a female character, as it is known that this element is frequently used to mark the female gender of Neolithic figurines ${ }^{17}$. The two characters are framed by groups, sets of zigzagging and winding lines connected to each other, along with other irregular incisions. These groups seem to represent a common element but drawn more and more chaotic as they are repeated. The scene is completed by rectangles with geometric elements inside (Pl. IV). What is this scene? What are all these elements that seem to be connected? There are two characters, one probably female, the other has no element to indicate the sex. Between them, there are various incised elements among which the winding lines could represent water ${ }^{18}$. We can speculate about the two rectangles that they represent settlements or houses. In this (subjective) interpretation we have two characters, one female, one possibly male (a "thinker"?) water, houses or settlements. Starting from these elements, various scenarios can be constructed, the limit being the personal imagination. In this case, things are more complicated because in addition to the significance of the scene, the significance of placing it on an artefact whose functionality is uncertain must be clarified.

As for the previous pieces, I emphasize my subjective perspective, trying to find a meaning using my historical background and my knowledge about the manner of representing the elements of that scene (and the term scene itself has a modern connotation).

The few artefacts above once again prove the complexity of what we call the Neo-Eneolithic age. Some researchers interpret some of the signs on such artefacts as evidence of Neolithic writing. The subject has been debated over time. In the last years several papers on this topic have been published ${ }^{19}$. The topic is vast and exciting. However it is not the subject of this article ${ }^{20}$.

This article aims to draw attention to aspects that are less taken into account when talking about the existence of such discoveries, perhaps related to an old writing. First of all, it is about the archaeological evidence, sources or material evidence. Thus, the oldest writing systems, such as the cuneiform, were deciphered due to a rich archaeological material discovered in the sites of that era. Researched settlements on large areas provided tens of thousands of clay tablets covered with cuneiform marks. It is a special support, multiplied in thousands and thousands of copies, on which these signs are located.

What is the situation in the case of the Neo-Eneolithic period? First of all, there are not many series of artefacts with signs such as the Mesopotamian clay tablets. There are very few artefacts, such as those described above or the tablets from Tărtăria, that are specially made to carry certain signs with a visual message. Most of them are on various supports, many on Neolithic figurines, but also on vessels, ceramic fragments, and clay weights. All these artefacts are collected from dozens of archaeological sites belonging to various Neo-Eneolithic cultures covering a very long period, of about three millennia. It is obvious that in these conditions it is very difficult to identify certain visual patterns that are validated as representing a writing system.

Thus we've reached an aspect that I have always emphasized, the lack of extensive archaeological research. In an article written more than a decade ago, I lamented the lack of extensive research in Neolithic settlements ${ }^{21}$. Unfortunately, the situation has not changed in the last decade, archaeological research being generally quite few and, very importantly, on small areas. Added to this is the publication to a very small extent of the research results (the artefact from Vădastra published above comes from excavations carried out in the sixties). This is the situation in southern Romania but can it be extended to the entire country. On the other hand, there are fewer archaeological researches covering the first part of the Neolithic (period to which the above artefacts belong) compared to those of the second part of the era, called Eneolithic or Chalcolithic. Archaeological research on small areas has little chance of discovering artefacts that certify, among other things, the existence of a Neolithic writing. For example, the settlement from Măgura-Buduiasca on the Teleorman Valley covers an area of over 30 ha and archaeological research has affected only an insignificant part of the Neolithic habitation, about 400 square meters, divided into several sondages. Research has shown that archaeological complexes are not found on this entire surface, especially pit-houses, huts, and rarely surface dwellings. There are areas where the habitation is

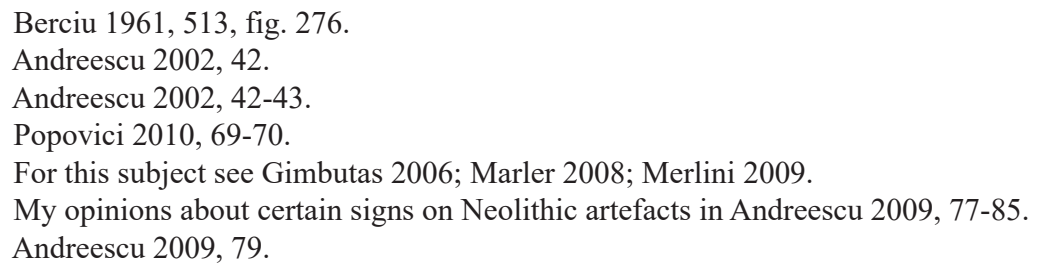


attested by several ceramic fragments or bones, located near areas with such archaeological complexes. These complexes belong to the Starčevo-Criş, Dudești and Vădastra cultures. We do not know the real extent of the settlements belonging to these cultures or their importance within them. However, although the researched area is very small, the excavations have brought to light three very interesting artefacts. How many such objects are in the complexes that are on the terrace of the Teleorman River? The answer to this question can only be given by extensive research that could lead to the discovery of large series of artefacts, which would allow the discovery of possible visual patterns.

The artefacts in this article along with the tablets from Tărtăria and other similar artefacts discovered in the Balkans represent a special category of discoveries. Unfortunately, they are few, usually singular in a site, sometimes without a clear archaeological context. Looking at them together, as they are above, it seems obvious that they are trying to convey something to us, either through signs or scenes. But what these artefacts really represent, what they are trying to convey to us, are questions that await their answer, along with countless other questions related to the fascinating Neo-Eneolithic age.

\section{Acknowledgments}

I want to express my gratitude to Dr. Alexandru Dragoman from the Vasile Pârvan, Institute of Archeology, Bucharest, for permission to study and publish the tablet discovered at Vădastra. I am also grateful to Dr. Pavel Mirea from the Teleorman County Museum, Alexandria for making the drawings of the pieces from MăguraBuduiasca, especially for the extremely difficult reconstruction of the scene unfolded from the seal piece and to Dr. Sabin Popovici from the Romanați Museum, Caracal, who provided us with the documentation about the artefact from Hotărani.

\section{BIBLIOGRAFIE}

Andreescu, R. 2002. Plastica antropomorfă gumelnițeană. Analiză primară. Monografii III. Muzeul Național de Istorie a României, București.

Andreescu, R. 2007. Valea Teleormanului. Considerații asupra plasticii antropomorfe. Studii de preistorie 4: 53-65. Andreescu, R. 2009. The sign: typology, context, meaning, in Sign and Symbols from Danube Neolithic and Eneolitic. Bibliotheca Brukental 35: 77-85.

Berciu, D. 1961. Contribuții la problemele neoliticului în România în lumina noilor cercetări. București: Editura Academiei Republicii Populare Romîne.

Dragoman, R-A. 2013. O biografie a ceramicii neolitice de la Vădastra. București: Editura Academiei Române.

Dumitrescu, Vl. 1980. The Neolithic settlement at Rast. BAR International Series 72.

Gimbutas, M. 2006. The language of the goddess. London: Thames\&Hudson.

Lazarovici, C-M. 2013. Pâini, plachete sau tăblițe de lut cu semne și simboluri in: Comșa A., Bonsall C. Nikolova L., (eds.) Facets of the past. The challenge of the Balkan Neo-Eneolithic: 560-573. București: Editura Academiei Române.

Lazarovici, Ghe. Lazarovici și C-M., Merlini, M. 2011. Tărtăria and the Sacred Tablets. Cluj-Napoca: Editura Mega.

Mateescu, C. 1971. Centenarul săpăturilor de la Vădastra. SCIV, 22, 4: 643-650.

Nikolov, V. 2006. Kultura i izkustvo na praistoričeska Trakiâ, Letera.

Marler, J. (ed.). 2008. The Danube Script: Neo-eneolithic Writing in Southern Europe. Catalogue of the Exhibition. Sibiu: National Brukental Museum, Sebastopol: Institute of Archaeomythology.

Merlini, M. 2009. An Inquiry into the Danube Script. seria Biblioteca Brukenthal XXXIII, Alba Iulia: Editura Altip.

Nica, M. 1971. Asupra originii şi dezvoltării culturii Vădastra pe baza descoperirilor de la Hotărani-Fărcaşele, jud. Olt. Historica II: 5-33.

Vlassa, N. 1963. Chronology of the Neolithic in Transylvania in the Light of the Tărtăria settlement's stratigraphy. Dacia N.S. 7: 485-494.

Popovici, S. 2010. O piesă inedită descoperită la Hotărani-La turn, jud Olt. Studii de preistorie 7: 65-70. 


\section{LISTA ILUSTRAṬIILOR}

Pl. I 1.Situri prezentate în text: 1. Măgura-Buduiasca; 2. Vădastra; 3 Hotărani; 2. Vedere aeriană a sitului MăguraBuduiasca, Valea Teleormanului (foto, R. Andreescu).

P1. II Artefacte: 1. Măgura-Buduiasca (foto, desen P. Mirea); 2. Vădastra (foto R. Andreescu; desen S. Movilă)

Pl. III Artefacte: 1; 2a,2b. Măgura-Buduiasca (foto, desene P. Mirea).

Pl. IV Artefact; Hotărani (foto, S. Popovici).

RADIAN-ROMUS ANDREESCU

National Museum History of Romania radian_romus@yahoo.com 

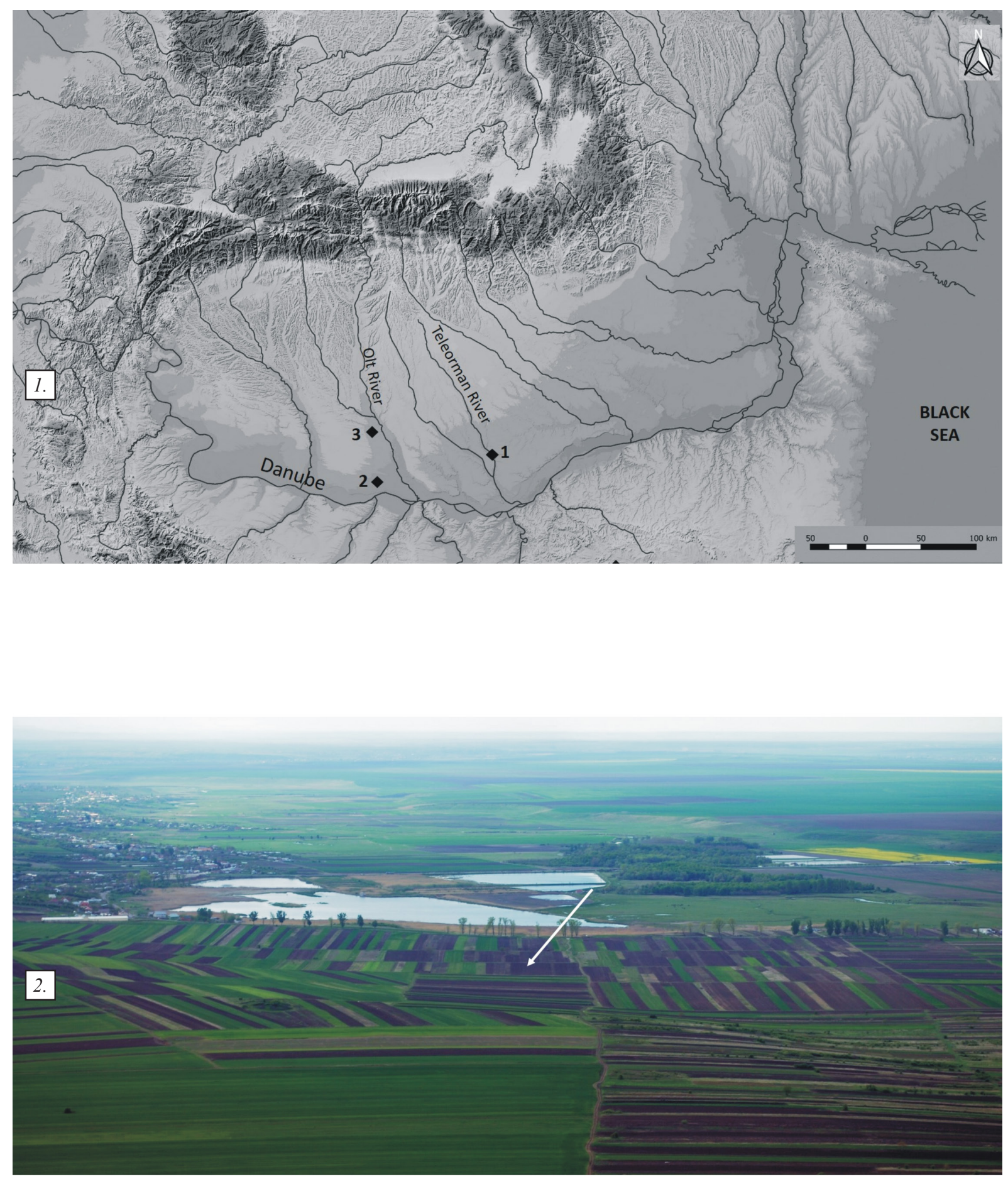

Pl. I 1. The sites presented in the paper: 1. Măgura-Buduiasca; 2. Vădastra; 3 Hotărani;

2. Aerial view of the Măgura-Buduiasca site, Teleorman Valley (photo by R. Andreescu). 

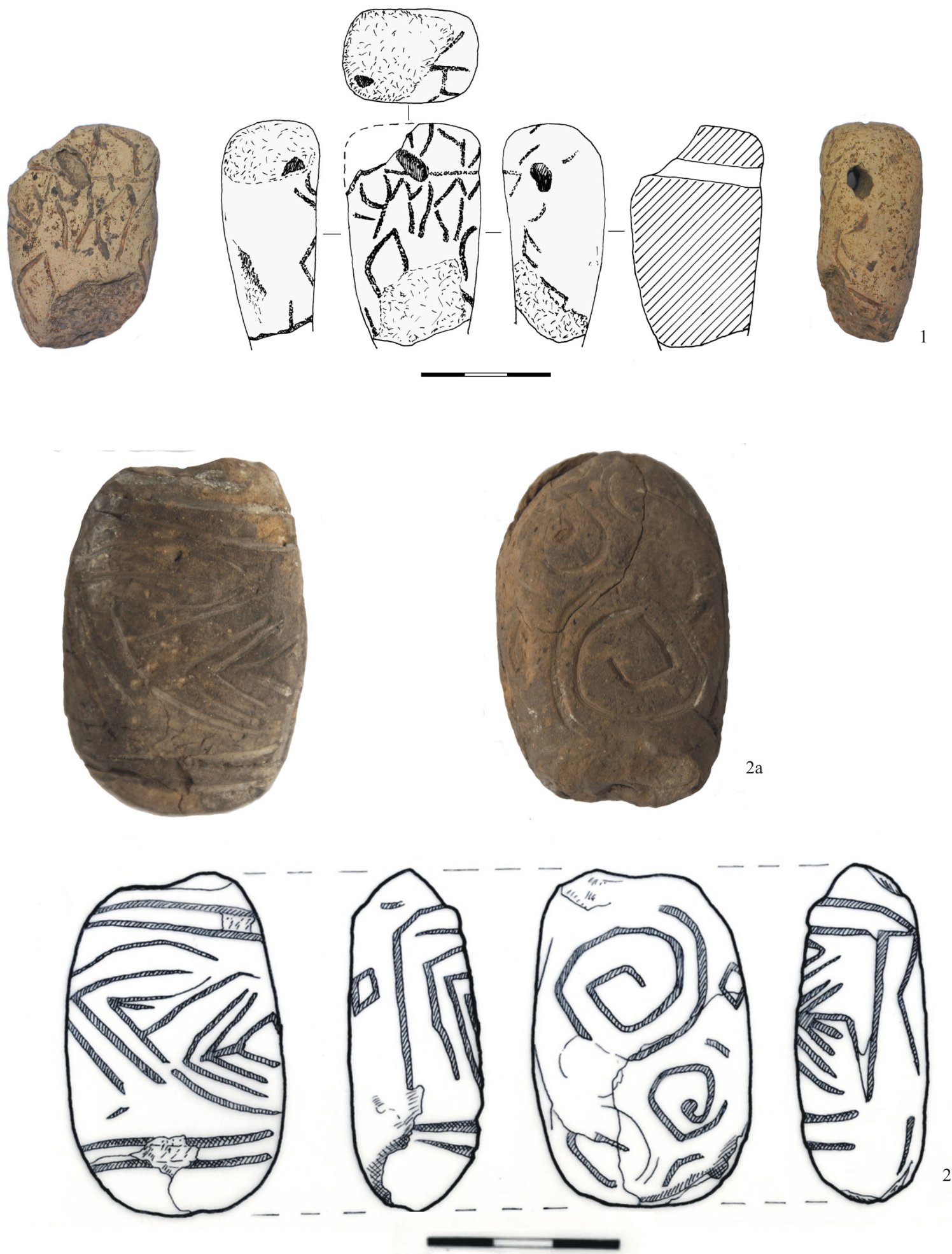

Pl. II Artifacts: 1. Măgura-Buduiasca (photos, drawing by P. Mirea); 2. Vădastra (photos by R. Andreescu; drawing by S. Movilă). 

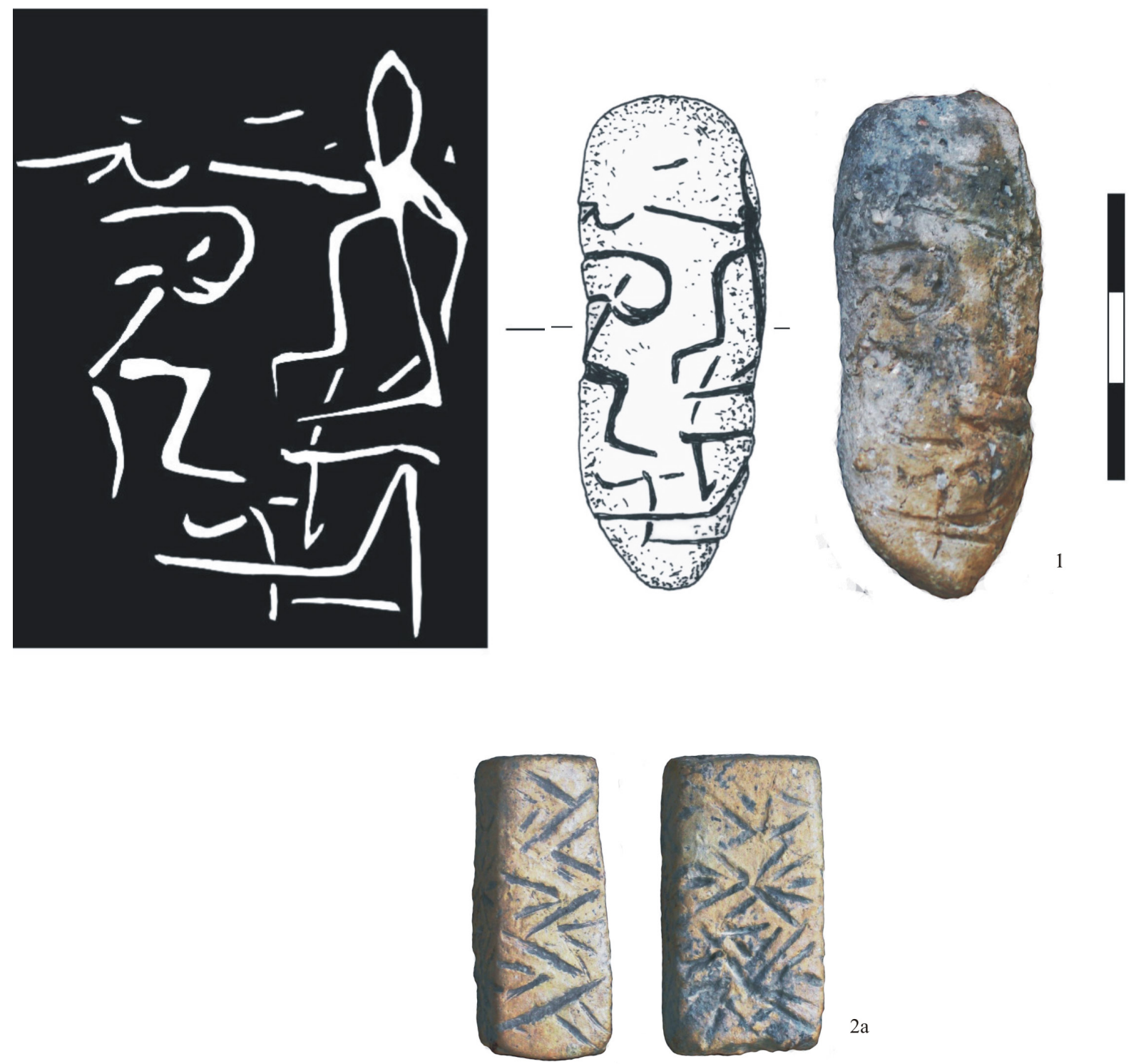

$2 a$
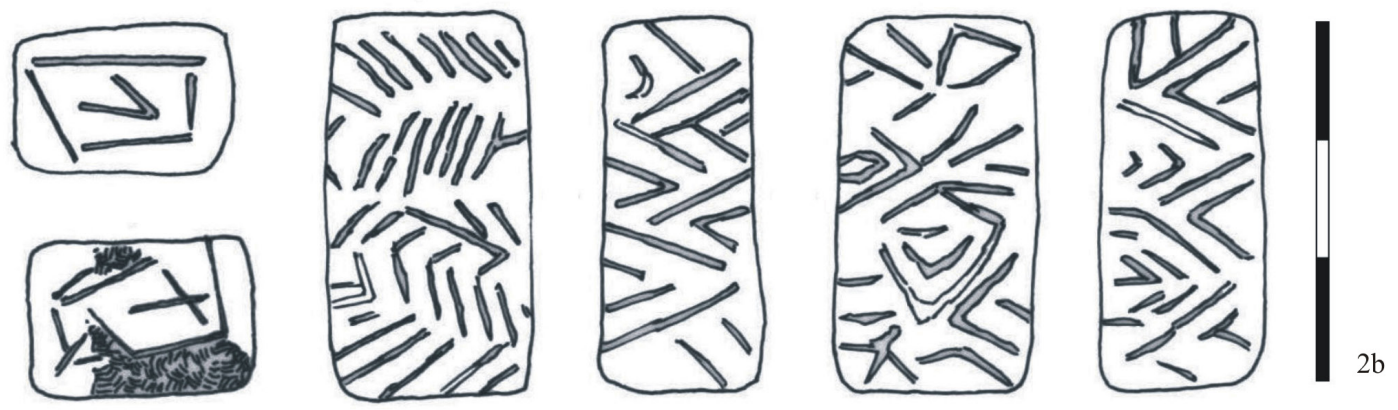

Pl. III Artifacts: 1; 2a, 2b. Măgura-Buduiasca (photos, drawings by P. Mirea). 

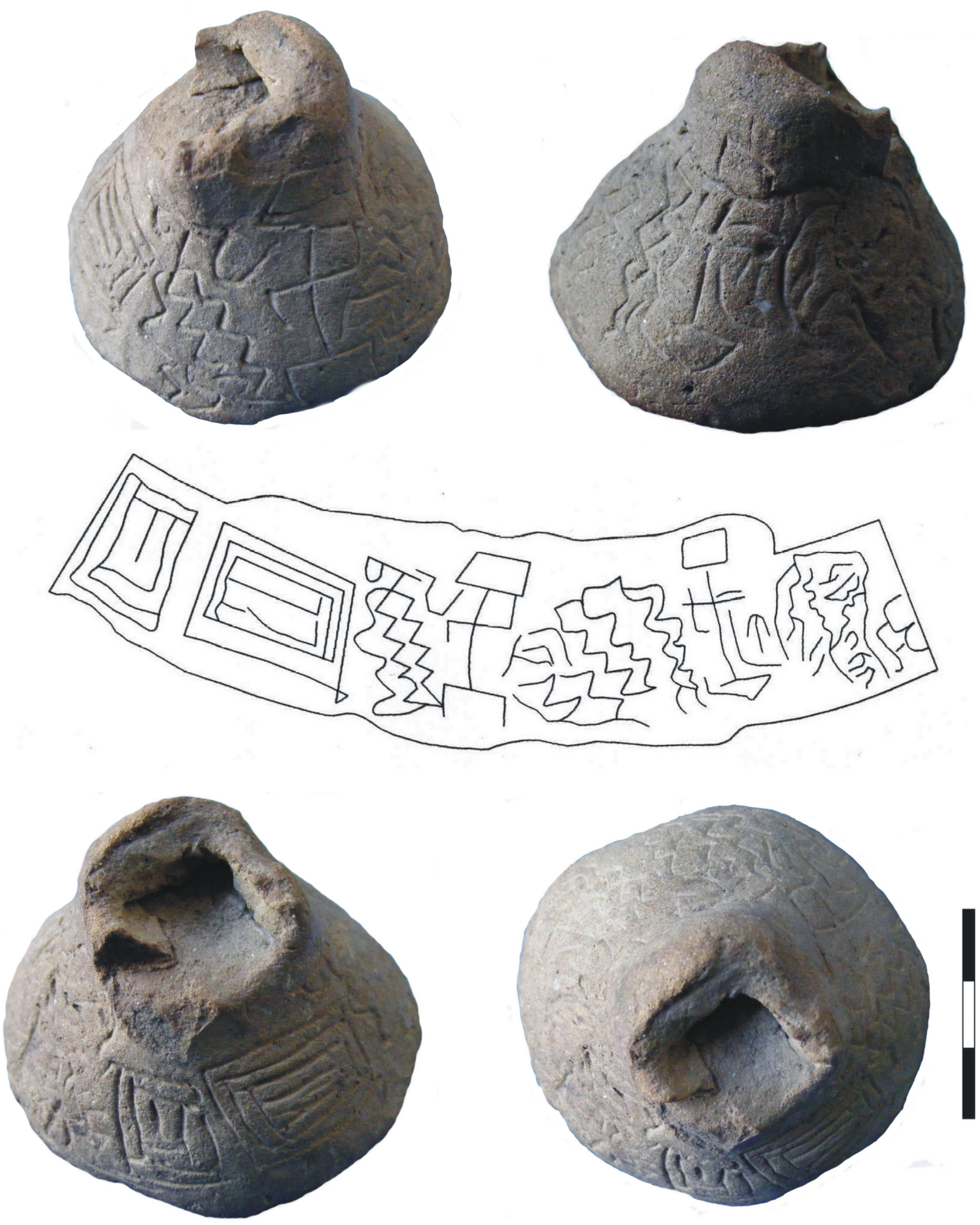

Pl. IV Artifact; Hotărani (photos by S. Popovici). 